$p$-ISSN 1693-9484, $e$-ISSN : 2621-8313

Majalah Ilmiah Bahari Jogja (MIBJ)

Vol. 17 No. 2, Juli $2019 \quad(10-26)$

DOI : 10.33489/mibj.v17i2.206

(C) 2019 Akademi Maritim Yogyakarta

BAHARI JOG]A

\title{
Pelayanan Dan Pengawasan Terhadap Pelintas Batas Di Pos Lintas Batas Darat Mota'ain Perbatasan Negara Indonesia - Timor Leste
}

\author{
Fraquelino Do Rosario Pinto ${ }^{1}$, Sahudiyono ${ }^{2 *}$ \\ ${ }^{1}$ Alumni DIII Ketalaksanaan Pelayaran Niaga, Akademi Maritim Yogyakarta \\ ${ }^{2}$ Ketalaksanaan Pelayaran Niaga, Akademi Maritim Yogyakarta, Jl. Magelang KM 4.4, \\ Yogyakarta 55284, Indonesia \\ *Corresponding Author. Email: $\underline{\text { sahudiyono60@gmail.com. Hp: } 085800435419}$
}

\begin{abstract}
Abstrak
Keputusan Timor Leste untuk memisahkan diri dari Republik Indonesia dan menjadi negara merdeka pada tanggal 20 Mei 2002, ternyata menyisakan masalah tersendiri antara Indonesia dan Timor Leste. Masalah-masalah tersebut terutama terjadi pada daerah-daerah perbatasan yang terbagi menjadi 2 (dua) yaitu perbatasan maritim dan perbatasan darat. Salah satu perbatasan darat terdapat di kabupaten Atambua di propinisi Nusa Tenggara Timur. Masalah-masalah krusial yang sering terjadi pada daerah-daerah perbatasan itu di antaranya, penyelundupan narkoba, senjata api, bahan bakar minyak (BBM), penyalagunaan visa/paspor dan penyelundupan orang atau tenaga kerja indonesia (TKI).

Penelitian ini dilakukan guna mendeskripsikan pelayanan keimigrasian di perbatasan serta mengidentifikasi permasalahan-permasalahan pelanggaran hukum serta motifmotifnya yang berhubungan dengan problematika di daerah perbatasan kedua negara Republik Indonesia dan Republik Demokratik Timor Leste. Jenis penelitian ini adalah penelitian kualitatif dengan menggunakan pendekatan deskriptif dilakukan dengan melakukan observasi serta memilih beberapa narasumber/informan terpilih secara acak yang terdiri dari pelaku pelintas batas dari kedua negara serta beberapa personil petugas pemberi layanan di kantor imigrasi pos perbatasan Atambua-Timor Leste.

Hasil penelitian menunjukkan bahwa pertama, pemerintah Indonesia telah memberikan pelayanan sekaligus pengawasan terhadap para pelintas batas, namun dalam pelaksanaannya masih ditemukan beberpa kekurangan seperti keterbatasan sarana prasarana, serta keterbatasan sumberdaya manusia secara kuantitatif dan kualitatif; yang kedua, masih ditemukan sejumlah permasalahan bidang ekonomi, hukum sosial-budaya, bahkan politik yang dampaknya masih terjadi berbagai pelanggaran hukum keimigrasian dan bentuk pelanggaran lainnya dari berbagai bidang tersebut baik yang dilakukan oleh penduduk /warganegara Indonesia maupun warganegara Timor Leste. Bentuk pelanggaran hukum berupa pelanggaran dokumen keimigrasian, penyelundupan, transaksi narkoba, dan perbuatan kriminal tertentu. Ketiga, direkomendasikan agar lebih ditingkatkan kerjasama dan keterpaduan antar instansi di dalam negeri baik pusat dan daerah serta antar instansi daerah terkait lainnya. Demikian pula kerjasama antar instansi-intansi nasional dengan intansi terkait dari negara Timor Leste.
\end{abstract}

Kata kunci: pelintas batas, pelanggaran hukum, keimigrasian, pemeriksaan 


\begin{abstract}
The decision of East Timor to separate itself from Republic Of Indonesia and become independent on May 20th,2002 remain an unsolved problem between the two countries. The existing problem lies in the borders between the two nations which is divided into two borders such as maritime and on-shore border. On of the on-shore border is Atambua regency in east Nusa Tenggara. Some problems which may occur in that region are drug and weapon smuggling, fuel smuggling, Passport and Visa abuse, human trafficking.

This research is aimed to identify and comprehend immigration services in the borders of the two nations as well as the problems due to the law violation that may occur including the triggering motives in the borders of those two countries. The type of the research is descriptive qualitative by taking data using observation and random interview toward those living nearby the border line and toward some immigration officers in the Atambua border line.

The result of the research showed that first, in fact Indonesian government had given good services as well as good supervision toward passersby in the border of the two nations, however, there were still many weaknesses due to the facilities and the quality and quantity of human resources. Second, there were still found many problems in economics, socio cultural, and politic affairs which lead to the violations toward immigration law and others conducted by both Indonesian citizens and East Timor citizen. Some of those violations were such as abuse of immigration documents, smuggling, drug abuse, and another crimes. Third, It is recommended that the cooperation and collaboration among institutions both in the center and regional level of Indonesia as well as cooperation between Indonesian government and East Timor government should be increased.
\end{abstract}

\title{
Keywords: Border Passerby, Law Violation, Immigration, Inspection
}

\section{PENDAHULUAN}

Wilayah Negara Kesatuan Republik Indonesia yang sangat luas memiliki kawasan perbatasan yang terdiri dari perbatasan darat yang berbatasan langsung dengan negara-negara Malaysia, Papua New Guinea (PNG), dan Timor Leste serta perbatasan laut yang berbatasan dengan 10 negara, yaitu India, Malaysia, Singapura, Thailand, Vietnam, Filipina, Republik Palau, Australia, Timor Leste dan Papua New Guinea (PNG). Perbatasan-perbatasan tersebut merupakan bentuk kedaulatan suatu negara yang memiliki luas wilayah yang tidak dapat diubah-ubah, di setiap perbatasan suatu negara pasti memiliki penjaga baik itu dari unsur Militer, Imigrasi, Bea Cukai, Balai Karantina maupun Badan Nasional Pengelola Perbatasan (BNPP) yang memiliki peran dan tanggung jawab masing-masing dalam mengelola wilayah perbatasan.

Di setiap daerah perbatasan, ada kalanya warga negara yang satu dengan segala kepentingannya harus melewati perbatasan negara untuk mengunjungi negara tetangga mulai dari pejabat, mahasiswa, turis atau penduduk setempat memiliki kepentingan pribadi atau tugas untuk melintas batas negara tersebut. Di setiap negara memiliki hukum dan peraturan masing-masing bagi pelintas batas, 
biasanya negara yang saling berbatasan membuat MoU (Memorandum of Understanding) atau biasa dikenal nota kesepahaman tentang bagaimana tata cara lintas batas antar negara tersebut, baik untuk berkunjung maupun berdiam sementara. Untuk mengatur hal tersebut, di Indonesia telah terdapat peraturan yang mengaturnya yaitu Undang-undang Republik Indonesia Nomor 6 Tahun 2011 yang menggantikan Undang-undang Nomor 9 Tahun 1992 tentang Keimigrasian.

Keputusan Timor Leste untuk memisahkan diri dari Republik Indonesia dan menjadi negara merdeka pada tanggal 20 Mei 2002, ternyata menyisakan masalah tersendiri antara Indonesia dan Timor Leste, masalah-masalah tersebut terutama terjadi pada daerah-daerah perbatasan. Perbatasan-perbatasan itu sendiri terbagi menjadi 2 (dua) yaitu perbatasan maritim yang terdapat pada beberapa titik, di antaranya Pulau Batek, Alor, Mangudu, Liran Wetar, Kisar, Leti, serta Meatimiarang. (Fauzan, 2011:11)

Sedangkan perbatasan darat terdapat pada beberapa titik, yaitu Kabupaten Belu, Timor Tengah Utara (TTU), serta Kupang. Perbatasan Republik Indonesia terbagi atas 2 (dua) sektor, yaitu (1) Sektor Timur di Kabupaten Belu yang berbatasan langsung dengan Distrik Covalima dan Distrik Bobonaro di Timor Leste sepanjang 149.1 kilometer, dan (2) Sektor Barat (Kabupaten Kupang dan Timor Tengah Utara) yang berbatasan langsung dengan Distrik Oecusse yang merupakan wilayah enclave Timor Leste sepanjang 119.7 kilometer. (Fauzan, 2012.29)

Beberapa kasus pelangaran keimigrasian yang sering dihadapi oleh instansi yang berwenang yaitu seperi : penyalagunaan dokumen perjalanan, penyelundupan narkotika, bahan bakar minyak, senjata api dan penyelundupan orang atau tenaga kerja Indonesia, selain itu terbatasnya sumber daya manusia dan sumber daya energi, sehingga masalah yang timbul menjadi penghambat berjalannya aktivitas pelayanan dan pengawasan terhadap pelintas batas.

Selain itu masalah-masalah krusial yang sering terjadi pada daerah-daerah perbatasan itu di antaranya, penyelundupan narkoba, senjata api, bahan bakar minyak (BBM), penyalagunaan visa/paspor dan penyelundupan orang atau tenaga kerja indonesia (TKI). (Wuryandari, 2009:217)

Permasalahan klasik di perbatasan RI-RDTL yang tak pernah terselesaikan yakni masalah penyelundupan dan pelintas batas illegal. Penyelundupan barang seperti kendaraan bermotor, dan bahan bakar minyak (BBM), serta pelintas batas illegal tidak juga dapat dituntaskan atau diselesaikan sejak Timor Timur menjadi negara berdaulat, pisah dari NKRI tahun 1999 hingga saat ini.

Mencermati permasalahan penyelundupan di perbatasan sebenarnya sangatlah mudah untuk dilakukan pencegahan, karena para pelaku penyelundupan (baik penyelundupan BBM, kendaraan dll) pasti menggunakan akses jalan utama sebelum melalui jalan yang dinamakan jalan tikus, pada lokasi inilah yang seharusnya perlu pengawasan ketat oleh para aparat. Sedangkan untuk permasalahan pelintas batas illegal diperbatasan RI-RDTL harus dicarikan solusi yang tidak memberatkan masyarakat di perbatasan dalam hal pengurusan dokumen keimigrasian seperti "menggratiskan" pengurusan pasport bagi warga baru (eks pengungsi Tim-Tim) utamanya yang berada diperbatasan atau pemberlakuan bebas visa ke RDTL, selain itu perlunya penambahan personil imigrasi.yang berdampingan dengan personil Polri,bea cukai dan TNI pada semua titik perbatasan 
tidak hanya di PLBN yang resmi ( PLBN Motaain, Motamasin, Wini) Demikianlah selintasan gambaran tentang permasalahan perbatasan RI- RDTL yang tak pernah terselesaikan, dengan harapan semoga anak anak yang saat ini duduk dibangku Sekolah Dasar di perbatasan, kedepannya tidak pernah mendengar lagi pemasalahan penyelundupan dan pelintas batas illegal, karena ketika mereka beranjak remaja semuanya sudah berubah kearah yang lebih baik, seperti pembangunan fisik maupun pembangunan mental. (http://www.kompasiana.com edisi 13 Desember 2016, diunduh 29 Mei 2017).

Artikel atas hasil penelitian ini dimaksudkan untuk memaparkan tentang pelayanan yang dilakukan Kantor Imigrasi Kelas II Atambua serta masalahmasalah yang timbul menjadi tanggung jawab Kantor Imigrasi Kelas II Atambua yang timbul dalam pelaksanaan pelayanan, pengawasan dan pemeriksaan bagi para pelintas perbatasan negara.

\section{Fungsi Pelayanan dan Pengawasan Keimigrasian}

Undang-undang Nomor 6 Tahun 2011 yang menggantikan Undang-undang Nomor 9 Tahun 1992 tentang Keimigrasian menegaskan, keimigrasian adalah hal ihwal lalu lintas orang yang masuk atau keluar wilayah Indonesia dan pengawasan orang asing di Indonesia, dalam rangka menjaga tegaknya kedaulatan negara. Fungsi keimigrasian adalah bagian dari urusan pemerintahan negara dalam memberikan pelayanan keimigrasian, penegakan hukum, keamanan negara dan fasilitator pembangunan kesejahteraan masyarakat. (M. Imam Santoso, 2004)

Tempat-tempat pelayanan keimigrasian meliputi bidang atau sub bidang keimigrasian pada perwakilan RI di luar negeri, di perjalanan dalam pesawat udara, maupun kapal laut, tempat pemeriksaan imigrasi, kantor imigrasi, bidang imigrasi pada Kantor Wilayah Departemen Kehakiman dan HAM, serta Direktorat Jendral Imigrasi. Fungsi Direktorat Jenderal Imigrasi adalah unsur pelaksana yang berada dibawah dan bertanggung jawab kepada Menteri Hukum dan Hak Asasi Manusia yang dipimpin oleh seorang Direktur Jenderal. (Pasal 528) Direktorat Jenderal Imigrasi menyelenggarakan fungsi: a) perumusan kebijakan di bidang imigrasi b) pelaksanaan kebijakan di bidang imigrasi, c) penyusunan norma, standar, prosedur dan kriteria di bidang imigrasi, d) pemberian bimbingan teknis dan evaluasi di bidang imigrasi dan e) pelaksanaan administrasi Direktorat Jenderal Imigrasi

Pelayanan keimigrasian menurut fungsinya diarahkan pada pelayanan: a) perpanjangan izin tinggal kunjungan, b) penerbitan Kartu Izin Tinggal Terbatas (KITAS) baru, c) perpanjangan Kartu Izin Tinggal Terbatas (KITAS), d) enerbitan Kartu Izin Tinggal Tetap (KITAP), d) perpanjangan Kartu Izin Tinggal Tetap (KITAP), e) alih jabatan atau sponsor, f) alih status izin tinggal, g) penambahan status pekerjaan (rangkap jabatan), h) Surat Keterangan Keimigrasian untuk pengajuan kewarganegaraan (Naturalisasi), i) Pengembalian Dokim/Pencabutan status Warga Negara Asing karena telah memperoleh kewarganegaraan RI, j) Izin Masuk Kembali (MERP/ERP), k) Izin Meninggalkan Indonesia untuk tidak kembali (EPO), 1) Pelaporan kelahiran, perkawinan, meninggal dunia, dan keluar wilayah RI tidak kembali, m) Pendaftaran untuk mendapatkan fasilitas keimigrasian kewarganegaraan ganda (Affidavit). (Pasall ayat 1 UU No. 6/2011) 


\section{Sistem Informasi Manajemen Keimigrasian}

Direktur Jendral Imigrasi bertanggungjawab menyusun dan mengelola sistem manajemen informasi keimigrasian yang bersifat secara rahasia sebagai sarana pelaksanaan fungsi keimigrasian didalam atau diluar wilayah Indonesia yang dapat diakses oleh instansi dan lembaga pemerintahan terkait sesuai dengan tugas dan fungsinya. (Pasal 7 UU No. 6/2011 tentang Keimigrasian).

Pada setiap Tempat Pemeriksaan Imigrasi ditetapkan suatu area tertentu untuk melakukan pemeriksaan keimigrasian yang merupakan area terbatas dan hanya dapat dilalui oleh pelintas batas yang akan keluar atau masuk wilayah Indonesia atau pejabat dan petugas yang berwenang dan diselenggarakan oleh Kepala Kantor Imigrasi bersama-sama penyelenggara perbatasan negara. (Pasal 22). Kewajiban Penanggung Jawab Alat Angkut: a) Penanggungjawab alat angkut yang masuk atau keluar Wilayah Indonesia dengan alat angkutnya wajib melalui tempat pemeriksaan Imigrasi, b) Penanggungjawab yang membawa alat angkut penumpang yang akan masuk atau keluar Wilayah Indonesia hanya dapat menurunkan atau menaikkan penumpang di Tempat Pemeriksaan Imigrasi

\section{Dokumen Perjalanan Republik Indonesia}

Dokumen perjalanan Republik Indonesia adalah Paspor Republik Indonesia dan Surat Laksana Paspor Republik Indonesia atau dokumen pengganti paspor yang diberikan dalam keadaan tertentu yang berlaku dalam jangka waktu tertentu dan merupakan dokumen resmi yang dikeluarkan oleh pejabat yang berwenang dari suatu negara, Peserikatan Bangsa-Bangsa, atau organisasi internasional lainnya untuk melakukan perjalanan antarnegara yang memuat identitas pemegangnya yang meliputi : foto pemegang, tanda tangan, tempat dan tanggal kelahiran, informasi kebangsaan dan kadang-kadang juga beberapa informasi lain mengenai identifikasi individual. Paspor diterbitkan oleh Menteri dalam/luar negeri atau Pejabat Imigrasi dan diberikan kepada calon pelintas batas sesuai dengan permohonan untuk melakukan perjalanan masuk/keluar Wilayah Indonesia sesuai dengan sifat perjalanannya. (Pasal 1 ayat 13 dan 16 UU No. 6/2011).

Beberapa jenis atau macam-macam paspor terdiri atas : paspor biasa, paspor diplomatic, paspor dinas/resmi, paspor untuk orang asing, paspor haji dan TKI (Tenaga Kerja Indonesia). Selain paspor ada juga dokumen lain Surat Perjalanan Laksana Paspor yakni dokumen pengganti paspor yang diberikan kepada Warga Negara Indonsia dan Warga Negara Asing jika paspor tidak dapat diberikan dalam keadaan tertentu dan berlaku dalam jangka waktu tertentu. (Pasal 1 Angka 17). Surat ini diberikan dalam hal a) atas kehendak sendiri keluar Wilayah Indonesia sepanjang tidak terkena pencegahan, b) ikenai deportasi atau c) repatriasi.

Selanjutnya visa adalah sebuah rekomendasi yang diberikan kepada Warga Negara Indonesia atau Warga Negara Asing atas permohonannya untuk dapat masuk dan keluar ke negara tujuan untuk melakukan perjalanan/tugas sesuai dengan jenis visa dan bukan berarti izin mutlak atau jaminan untuk dapat masuk ke negara tujuan. Keputusan terakhir untuk dapat masuk atau tidak ke negara yang dituju akan diberikan oleh pihak Imigrasi.Visa terdiri atas : visa diplomatik, visa dinas, visa kunjungan dan visa tinggal terbatas.

Dokumen selanjutnya yang lain adalah Pas Lintas Batas (PLB). Berdasarkan Arragement betwen the governement of the republik of indonesia and the 
government of the Democratica Republic of Timor Leste on traditional border crossings and regulated market (Arrangement 2003) yang ditandatangani pada Juni 2003, Pemerintah Indonesia dan Timor Leste memberlakukan Pas Lintas Batas (PLB) bagi masyarakat yang tinggal di perbatasan darat RI-TL. PLB merupakan dokumen perjalanan yang berfungsi sebagai paspor (dan sekaligus visa) bagi masyarakat yang tinggal menetap di wilayah perbatasan darat RI-TL. PLB berlaku selama 1 tahun, untuk beberapa kali perjalanan, dengan masa tinggal di Timor Leste (bagi WNI) selama 10 hari dan dapat diperpanjang selama 2 (dua) kali atau untuk maksimal 30 hari. Persyaratan untuk mendapatkan PLB adalah : a) Mengisi formulir dan kemudian dilegalisir oleh Kepala Desa setempat b) Akte Kelahiran/ surat baptis dari Gereja c) KTP d) Pas foto dan Surat Keterangan Catatan Kepolisian (SKCK).

Pihak-pihak yang terkait dalam pelayanan, pengawasan dan keamanan di wilayah perbatasan

a) Badan Nasional Pengelola Perbatasan (BNPP)

Menurut pasal 3 UU No 12 tahun 2010 BNPP sendiri mempunyai tugas menetapkan kebijakan program pembangunan perbatasan, menetapkan rencana kebutuhan anggaran, mengkoordinasi pelaksanaan dan melaksanakan evaluasi pengawasan terhadap pengelolaan batas wilayah dan kawasan perbatasan.

\section{b) TNI/POLRI}

Menurut UU/2004 tentang Tentara Nasional Indonesia bagian (C) bahwa TNI sebagai alat pertahanan NKRI, bertugas melaksanakan kebijakan pertahanan negara untuk menegakkan kedaulatan negara, mempertahankan keutuhan wilayah, dan melindungi keselamatan bangsa, menjalankan operasi militer untuk perang dan operasi militer selain perang, serta ikut secara aktif dalam tugas pemeliharaan perdamaian regional dan internasional.

\section{c) Bea dan Cukai}

Menurut Undang-undang No. 22/1997 dan UU No. 35/2009, narkotika dan psikotropika dilarang masuk ke wilayah RI. Ada juga beberapa jenis flora dan fauna yang dilarang masuk/keluar wilayah RI karena terancam punah. Selain itu, Bea Cukai juga bertugas mengawasi adanya perdagangan senjata api dan melindungi benda cagar budaya yang melintas di perbatasan, baik darat, laut, maupun udara.

\section{d) Karantina/Dinas Kesehatan}

Menurut PP. RI No. 14/2002 Tentang Karantina bahwa tugas karantina adalah melaksanakan fungsi pemerintahan tentang pembinaan, pengaturan dan pengawasan atas lalu lintas orang, tumbuh-tumbuhan dan hewan guna mencegah penularan penyakit.

\section{METODE}

Jenis penelitian ini adalah penelitian kualitatif dengan menggunakan pendekatan deskriptif ditunjang dengan metode dokumentasi dengan kajian referensi, peraturan-peraturan hukum serta data sekunder lainnya dari berbagai sumber termasuk internet. Pengumpulan data dilakukan dengan 3 metode, yakni observasi, interview dan dokumentasi. Observasi dilakukan oleh petugas (peneliti) lapangan dengan cara secara langsung ikut bergabung melibatkan diri bersama

Majalah Ilmiah Bahari Jogja 15 | http://jurnal.amy.ac.id/index.php/MIBJ/ 
personil petugas terpadu di Pos Lintas Batas Mota'ain. Interview dilakukan petugas dilengkapi dengan panduan interview, dengan memilih beberapa narasumber/informan terpilih secara acak yang terdiri dari pelaku pelintas batas dari kedua negara serta beberapa personil petugas pemberi layanan di kantor imigrasi pos perbatasan Atambua-Timor Leste.

\section{HASIL DAN PEMBAHASAN}

\section{Pelayanan dan Pelaksanaan Pemeriksaan Keimigrasian atas Kendaraan Pelintas Batas di Perbatasan}

Kantor Imigrasi Kelas II Atambua telah membawahi 3 Tempat Pemeriksaan Imigrasi dan 6 Pos Imigrasi disetiap daerah perbatasan Republik IndonesiaRepublica Democratica de Timor Leste (RDTL), salah satunya yaitu tempat pemeriksaan imigrasi Mota'ain yang berfungsi juga sebagai Pos Lintas Batas Darat (PLBD) yang terhubung dengan Batugade Timor Leste dengan jarak $40 \mathrm{~km}$ dari Kota Atambua dengan jalan aspal ( \pm 45 menit).

TPI Mota'ain juga merupakan salah satu pintu keluar masuk wilayah Indonesia yang terletak di pesisir pantai utara pulau Timor yang cukup ramai dengan jumlah pelintas rata-rata 150-200 orang setiap harinya. Pada TPI Mota'ain, pelaksanaan fungsi CIQS (Customs, Immigration, Healty Quarantine and Security) sudah berjalan namun belum dilengkapi dengan infrastruktur yang semestinya. Petugas Imigrasi yang ditempatkan pada TPI Mota'ain, 5 orang petugas dan dikoordinir 1 orang pejabat teknis Imigrasi.

Kegiatan pelayanan dan pengawasan terhadap lalu lintas orang yang keluar maupun masuk (arrival and departure) wilayah Indonesia akan berlangsung dan bergerak secepat mungkin apabila petugas Imigrasi (Immigration) bekerja sama dengan instansi yang berwenang seperti : Bea Cukai, Karantina Kesehatan, TNI dan Polri sehingga pelayanan dan pengawasan terhadap keluar masuk pelintas batas (arrival and departure) dapat berjalan dengan lancar dan cepat.

\section{Langkah-Langkah Pelayanan dan Pemeriksaan Pelintas Batas}

Sebelum alat angkut bersama calon pelintas batas tiba dan memasuki area Imigrasi maka instansi yang berwenang di pos lintas batas darat Mota'ain melakukan persiapan dalam melayani kebutuhan maupun pengawasan untuk keberangkatan pelintas (Departure) ke Timor Leste. Persiapan yang dilakukan Petugas Imigrasi sebelum menangani keberangkatan pelintas batas yaitu a) Menyiapkan kartu keberangkatan/kedatangan di loket keberangkatan WNI, persiapan ini dilakukan agar tidak terjadi antrian yang panjang saat pelintas akan merapat ke loket pelayanan. b) Menyiapkan $H T$, persiapan ini dilakukan agar adanya pertukaran informasi antara petugas pengawasan area Imigrasi dengan petugas pelayanan di loket keberangkatan (departure) c) Menyiapkan Microsoft Office Excel untuk mendata keberangkatan pelintas, persiapan ini dilakukan untuk mengurangi menumpuknya pengetikkan data harian perlintasan. d) Menyetel tanggal pada setiap cap baik untuk kedatangan ataupun keberangkatan seperti, cap Crew Visit untuk orang asing, cap kedatangan untuk Pas Lintas Batas WNI, cap kedatangan untuk Border Crossing Pass, cap Dinas/Diplomatik untuk orang asing, 
cap Visit Visa, cap Limited Stay Permit, cap Visa Exemption dan juga menyiapkan cap Use dan Cancel.

Tempat pemeriksaan imigrasi Mota'ain menetapkan area Imigrasi yang merupakan area terbatas untuk melakukan pemeriksaan keimigrasian dan hanya dapat dilalui oleh pelintas batas yang akan keluar atau masuk wilayah Indonesia atau pejabat dan instansi berwenang dan diselenggarakan oleh kepala kantor imigrasi bersama-sama penyelenggara perbatasan negara.

Setelah alat angkut tiba dan memasuki area Imigrasi maka penangung jawab alat angkut (pengemudi) segera kembali melaporkan dan memberitahu kembali kedatangan kepada masing-masing instansi diantaranya : 1) Securirty/Keamanan (TNI dan POLRI), 2) Customs/Bea dan Cukai 3) Immigration/Imigrasi dan 4) Healty Quarantine/Karantina Kesehatan.

Dalam pemberitahuan ke pihak Keamanan/Security (TNI dan POLRI) penangung jawab alat angkut (pengemudi) memberitahukan kedatangannya dengan melampirkan salinan Daftar Penumpang/Manifest. Selanjutnya pelintas batas melaporkan diri pada pihak petugas piket keamanan untuk didata, data yang diambil berdasarkan biodata yang tertera pada halaman identitas pemegang paspor, beberapa data yang diambil dari pelintas batas baik WNI ataupun WNA yaitu nama, informasi kebangsaan, nomor paspor, jenis paspor dan identitas lainnya. Terhadap barang harus dilakukan pemberitahuan ke pihak Bea Cukai /Customs. Kantor Pelayanan Bea dan Cukai menerima salinan daftar penumpang dari penanggung jawab alat angkut di pos pemeriksaan Bea Cukai, bila diketahui barang bawaan pelintas melebihi jumlah yang telah ditentukan atau diketahui barang larangan maka segera dilakukan pemeriksaan fisik oleh petugas Kepabeanan.

Sedangkan Pemberitahuan ke pihak Imigrasi/Immigration dilaksanakan oleh kordinator Tempat Pemeriksaan Imigrasi Mota'ain/Supervisor menunjuk dan membagikan tugas kepada setiap petugas, adapun tugas dan tanggung jawab bagi masing-masing petugas yaitu: a) Petugas di area Imigrasi terlebih dulu telah mengambil passenger list/daftar penumpang dan melakukan pemeriksaan kesesuain data, pemeriksaan meliputi : jumlah penumpang/calon pelintas batas, jenis kelamin dan umur, setelah selesai pemeriksaan maka petugas melaporkan data tersebut kepada petugas di loket pelayanan dan kembali mengawasi dan memantau aktivitas pelintas di area Imigrasi agar mencegah adanya pelintas yang tidak melalui tempat pemeriksaan, bila ada yang hal mencurigakan maka akan diberitahu kepada petugas loket pelayanan melalui $H T$.

Petugas Loket Pelayanan segera melaksanakan pelayanan keberangkatan (departure) setelah pelintas batas mengantri, pelayanan dibagi menjadi dua bagian yaitu : 1) Pelayanan untuk pelintas pemegang paspor Republik Indonesia (WNI), pelintas wajib menunjukan paspor untuk memperoleh kartu keberangkatan dan kedatangan yang belum terpisahkan/Id Card, selanjutnya pelintas mengisi fom sesuai dengan identitas yang tertera pada halaman paspor dan diserahkan kepada petugas dengan menyelipkan Id Card pada halaman paspor yang masih kosong untuk dicap. Sebelum membubuhi cap pada Id Card dan halaman paspor. Petugas memeriksa kesesuain penulisan data antara biodata pelintas dengan yang tertulis pada Id Card, apabila dalam pengecekan terdapat ketidaksesuain maka petugas akan mengganti dengan Id Card yang baru kepada pelintas untuk diisi kembali agar 
tidak menyulitkan petugas ketik dalam mendata keberangkatan pelintas harian. Setelah membubuhi cap petugas memeriksa secara teliti mengenai identitas pelintas apabila dalam pemeriksaan pelintas yang bersangkutan masuk dalam penyusunan daftar nama warga negara Indonesia yang dikenai pencegahan dan penangkalan untuk keluar Wilayah Indonesia maka akan ditolak keberangkatannya setelah berkoordinasi dengan Kordinator Imigrasi, selain itu Date of Expiry harus diperhatikan sehingga tidak memberangkatkan pelintas yang paspornya sudah tidak layak dipakai, selanjutnya petugas melakukan wawancara singkat terhadap pelintas khusunya yang berasal dari luar Pulau Timor, dengan pertanyaan-pertanyaan singkat seperti : apa tujuan ke Negara Timor Leste, berapa lamakah anda berada di Timor Leste serta dipastikan ada kesesuain visa dengan tujuannya. Bila dalam wawancara pelintas memberikan pernyataan yang tidak sesuai atau tidak benar dan terdapat keraguan maka petugas akan membubuhi cap Cancel pada cap keberangkatan yang terdapat pada halaman paspor dan Id Card sekaligus untuk pelintas pekerja agar melampirkan Visa Kerja.

Pelayanan untuk pelintas pemegang paspor asing (WNA) untuk keberangkatan dibagi dalam beberapa kategori dokumen perjalanan yaitu : 1) Pelayanan untuk Warga Negara Timor Leste (WNTL) kembali menyerahkan departure card yang diperoleh sewaktu memasuki wilayah Indonesia kepada petugas untuk dicap keberangkatannya kecuali yang menggunakan via pesawat udara, yang harus diperhatikan petugas yaitu ijin tinggal apabila ijin tinggal lebih dari 1 (satu) hari/overstay maka akan dikenakan biaya Administrasi Keimigrasian. Sedang pelayanan untuk Warga Negara Asing (WNA). Pemerintah Timor Leste memberlakukan aturan bahwa orang asing selain warga negara Indonesia dan warga negara Portugal untuk dapat masuk ke negaranya diwajibkan untuk memiliki Visa Authorization/Otoritas Visa. Bila dalam pelayanan terdapat hal demikian maka orang asing tersebut tidak dapat di berangkatkan, untuk dapat melintas maka pelintas segera mengurusnya pada Konsulat Timor Leste yang berada di Kupang NTT.

Pelayanan untuk pelintas Tradisional sama seperti pelayanan pada umumnya, namun terdapat perbedaan yaitu terletak pada dokumen perjalanan Pas Lintas Batas (PLB) untuk WNI dan Border Crossing Pass untuk warga negara Timor Leste yang dibebaskan dari biaya visa, petugas memperingatkan pelintas pemegang PLB agar melakukan perjalanan untuk tidak melewati batas wilayah yang sudah ditentukan kedua negara. Pelayanan untuk pelintas pelintas Crew/Ekspedisi baik orang Indonesia atau orang asing diwajibkan untuk melampirkan surat keterangan dari perusahaan yang mempekerjakan pelintas tersebut/ Immigration Clearance.

Setelah selesai pemeriksaan maka pelintas yang telah mendapatkan tanda keluar berupa cap pada halaman paspor dan Id Card akan dianggap sedang berada di luar wilayah Indonesia sehingga yang bersangkutan diharuskan meninggalkan area Imigrasi dan berangkat ke negara Timor Leste. Selanjutnya petugas melakukan pengumpulan data pelayanan lalu lintas Keimigrasian harian, baik warga negara Indonesia maupun warga negara asing yang keluar atau masuk wilayah Indonesia pada hari itu juga yang nantinya akan dimasukan dalam data bulanan keberangkatan dan kedatangan perlintasan yang wajib dilaporkan kepada Kantor Imigrasi Kelas II Atambua. 
Pemberitahuan ke pihak Karantina Kesehatan/Healthy Quarantine. Petugas Karantina Kesehatan menerima salinan Passenger List/Daftar Penumpang dari penanggung jawab alat angkut (pengemudi), selanjutnya petugas mendata identitas pelintas dan melakukan pemeriksaan kesehatan terhadap pelintas batas. Setelah pelintas batas melalui seluruh pelayanan dan proses pemeriksaan dan dalam pengawasan TNI di pintu gerbang maka pelintas yang telah mendapat tanda keluar akan segera meninggalkan area Imigrasi dan memasuki wilayah Timor Leste.

\section{Langkah-Langkah dalam Melayani Kedatangan Pelintas Batas dari Timor Leste (Arrival)}

Adapun langkah-langkah dalam mengurusi Kedatangan/Arrival pelintas batas yaitu: Sebelum pelintas tiba dan memasuki wilayah Indonesia, terlebih dulu penanggung jawab alat angkut telah melaporkan kedatangannya ke instansi yang berwenang di area Imigrasi dengan melampirkan Passenger List (Arrival). Pelayanan yang diberikan beberapa instansi yakni: 1) Pelayanan Karantina Kesehatan/Healthy Quarantine, Petugas Karantina Kesehatan mendata dan memeriksa pelintas, pemeriksaan yang dilakukan meliputi : pemeriksaa kesehatan pelintas batas dan pemeriksaan makanan yang berlabel (tanggal kadaluarsa) 20 Pelayanan Imigrasi/Immigration, petugas imigrasi menerima Passenger List/Daftar penumpang dari penanggung jawab alat anggkut dilanjutkan melakukan persiapan dalam melayani kedatangan pelintas batas WNA maupun WNI yaitu : menyiapkan Id Card asing untuk WNA, dan menyiapkan microsoft office untuk mendata arrival pelintas. Pelintas segera menggantri ke loket pelayanan, pelayanan keimigrasian dibagi menjadi dua bagian yaitu : untuk pelayanan untuk pelintas WNI, pelintas menyerahkan paspor bersama Id Card Kedatangan yang di beri sewaktu berangkat ke Timor Leste untuk dicap kedatanagan oleh petugas, kartu Kedatangan kembali diambil petugas untuk didata kedatangan pelintas WNI. Sedangkan pelayanan untuk pelintas asing/WNA, ada beberapa hal yang perluh diperhatikan dalam melayani pelintas asing khususnya untuk Warga Negara Timor Leste yaitu : a) Pemegang paspor umum Timor Leste, setelah petugas loket menerima paspor dan id card yang telah diisi dan sebelum membubuhi cap petugas memeriksa indeks visa pada halaman paspor dan selanjutnya melakukan wawancara singkat, apabila pelintas tersebut seorang Pelajar pemegang paspor baru maka diwajibkan untuk melampirkan paspor lama dan Surat Rekomendasi. b) Pemegang paspor Dinas/Diplomatik Timor Leste harus melampirkan surat Dinas. c) Pemegang Border Crossing Pass Timor Leste, dokumen ini diperingatkan petugas agar tidak melintas sampai ke Kota Atambua, karena dokumen ini hanya berlaku pada radius $10 \mathrm{~km}$ dari daerah perbatasan. d) Surat Tanda Penerimaan Paspor (STPP), dalam keadaan darurat Petugas Imigrasi dapat memberikan tanda masuk yang bersifat darurat kepada orang asing dan berlaku sebagai Izin Tinggal Kunjungan dalam jangka waktu tertentu berupa STPP. e) Pelintas Rombongan; Untuk pelintas rombongan diwajibkan melampirkan daftar nama rombongan agar mempermudah petugas dalam pelayanan.

\section{Pelayanan untuk Pelintas Pelangar Keimigrasian/ Deportasi}

Deportasi adalah tindakan paksa mengeluarkan orang asing dari wilayah Indonesia dan atau orang Indonesia yang dipaksa keluar dari negara asing. 
a ) Deportasi Warga Negara Timor Leste oleh Negara Indonesia

Sebelum memberikan tanda keluar kepada pelanggar keimigrasian/ Deportasi terlebih dulu petugas Imigrasi menerima Surat Pelaksanaan Tindakan Administratif Keimigrasian/ Surat Pelaksanaan Deportasi ( Lampiran 20 ) dan Single Temporary Travel Document (Lampiran 21 ) selanjutnya data tersebut dimasukkan dalam daftar nama penangkalan orang asing.

b ) Deportasi Orang Indonesia oleh Negara Timor Leste

Petugas Imigrasi menerima Delivery Term ( Lampiran 22 ) dari petugas Imigrasi Timor Leste, selanjutnya petugas Imigrasi pos Mota'ain mengarahkan perorangan ke dalam pos pemeriksaan untuk didata dan paspor yang bersangkutan ditahan dengan memberikan STPP sesuai dengan angka 1 atau 3 dan dalam jangka waktu 7 hari yang bersangkutan harus melapor ke Kantor Imigrasi Kelas II Atambua.

Selain pelayanan dan pengawasan TPI Mota'ain juga melayani penerbitan Pas Lintas Batas (PLB) untuk WNI denngan memenuhi persyaratan yang harus dipenuhi: 1) mengisi formulir dan kemudian dilegalisir oleh Kepala Desa setempat, 2) Akte Kelahiran/ surat baptis dari Gereja, 3) Pas foto dan Surat Keterangan Catatan Kepolisian (SKCK) dan KTP. Bila semua persyaratan terpenuhi maka pemohon langsung datang ke TPI Mota'ain untuk pengurusan PLB.

\section{Problematika Pelayanan dan Pengawasan Pelintas Batas}

Wilayah perbatasan sebagai batas kedaulatan suatu negara memiliki fungsi strategis dalam penentuan kebijakan pemerintah, baik untuk kepentingan intern maupun ekstern. Kepentingan intern berhubungan langsung dengan kepentingan nasional sebagai sebuah negara yang merdeka dan berdaulat. Bagi Indonesia, kepentingan ini sangat erat hubungannya dengan perwujudan wawasan nusantara untuk meningkatkan kesejahteraan bangsa. Kepentingan ekstern terkait dengan hubungan antarnegara pada skala regional dan internasional. Tidak dapat dihindari sebagai sebuah negara yang diakui kedaulatannya tentu berhubungan dengan negara-negara lain di tingkat internasional. Perbatasan yang jelas pada sebuah negara memberi kesempatan bagi negara tersebut untuk mempertahankan kedaulatan dan eksistensi berkembang di tataran Internasional.

Posisi geografis RI sangat berkaitan dengan perbatasan wilayah antarnegara sangat rawan. Posisi geografis RI yang diapit oleh dua benua mempunyai batas wilayah internasional dengan 10 negara tetangga. Perbatasan di darat terdiri dari 3 negara, yaitu Malaysia, Papua Nugini (PNG), dan Timor leste. Sedangkan sebagai negara kepulauan (archipelago state), Indonesis mempunyai batas maritim berupa batas laut wilayah (teritorial), batas landas kontinen, dan batas Zone Ekonomi Ekslusif (ZEE) dengan 10 negara, yaitu India, Thailand, Malaysia, Singapura, Vietnam, Filiphina, Palau, PNG, Timur Leste, dan Australia. Kekuatan hukum batas laut ini juga telah diatur melalui ratifikasi Konvensi Hukum Laut PBB UNCLOS 1982 melalui Peraturan Pemerintah RI Tahun 1985 dan Undang-undang RI No. 5 Tahun 1983 tentang Zona Ekonomi Eksklusif Indonesia. Perkembangan hubungan internasional yang begitu cepat dalam masa globalisasi pada akhirnya 
membuat keberadaan semua perangkat hukum tersebut menjadi kehilangan kekuatan dan keterkinian dalam mengatur hubungan internasional.

Banyak faktor yang menyebabkan penanganan perbatasan negara tidak mudah diselesaikan. Masalah ini bahkan memerlukan suatu penanganan yang sangat seirus dan lintas sektoral atau interdepartemental. Setiap negara memang memiliki kewenangan untuk menetapkan sendiri batas-batas wilayahnya. Namun mengingat batas terluar wilayah negara senantiasa berbatasan dengan wilayah atau perairan kedaulatan (yurisdiksi) dan otoritas negara lain, maka penetapan tersebut harus memperhatikan kewenangan otoritas negara lain sehingga perlu ada suatu kerjasama.

Kerjasama regional di bidang survei dan penegasan batas wilayah darat antara RI dengan negara tetangga selama ini biasanya tertuang dalam bentuk MoU dan perjanjian penetapan garis batas laut dan batas darat. Kerjasama tersebut memang dapat dilaksanakan, tetapi tidak jarang di dalam jalannya juga mengalami benturanbenturan. Kondisi lain yang turut mempersulit posisi Indonesia adalah, meskipun MoU dan persetujuan tersebut telah disepakati dan dibuat, kekuatan hukum melalui penatapannya dengan undang-undang kadang-kadang tidak dilakukan. Kondisi kekosongan hukum tersebut menyebabkan posisi Indonesia menjadi lemah ketika mendapatkan rongrongan dari bangsa lain. Kenyataan ini terbukti dari harus direlakannya Sipadan dan Ligitan kepada Malaysia.

Wilayah Indonesia yang sangat luas dan berpotensi, memang sangat rentan terhadap berbagai masalah perbatasan. Kekurangan sumber daya manusia yang potensial untuk menangani masalah tersebut membuat wilayah Indonesia yang berada di perbatasan dengan negara lain akan sangat mudah dicaplok oleh negara didekatnya. Realitas dari hal tersebut adalah bergesernya batas-batas antarnegara yang telah dibuat dan disepakati di sepanjang batas darat beberapa kawasan, misalnya antara Indonesia - Malaysia di Kalimantan Barat dan Papua dengan PNG. Segmen-segmen (gap) di sepanjang perbatasan antarnegara yang lama masih banyak yang belum diselesaikan. Sekarang ini dengan keberadaan Timor Leste tentunya segmen tersebut semakin bertambah dan menjadi PR tambahan bagi penanganan masalah perbatasan untuk pemerintah.

Persoalan wilayah perbatasan bukan hanya sekedar menegaskan garis wilayah atau batas negara saja. Penetapan tersebut perlu ditindaklanjuti dengan prosedur dan mekanisme hukum yang jelas. Itikad baik dalam melaksanakan MoU, persepakatan, dan juga hukum yang dibuat juga perlu mendasari hubungan baik antarnegara. Tidak kalah penting, pengelolaan wilayah batas negara dan segala kebijaksanaan yang menyertainya juga harus melibatsertakan warga negara, khususnya yang berada di daerah perbatasan secara aktif. Kasus-kasus yang selama ini banyak terjadi di perbatasan pada dasarnya dapat dikategorikan menjadi: 1) Pelanggaran prosedur keimigrasian, yaitu pelintas batas secara ilegal. Masalah ini juga yang berekses pada banyaknya jumlah TKI bermasalah di Malaysia dan menyelundupnya pelaku kejahatan/teroris. 2) Penyelundupan barang/orang secara illegal. Kasus ini sekarang ini berkembang dalam bentuk trafficking (wanita dan anak-anak) dan perdagangan barang-barang "haram" (narkotika dan obat terlarang). 3) Pencurian sumber daya alam pada wilayah-wilayah yang sulit atau jauh dari jangkauan pengawasan, misalnya pembalakan hutan secara ilegal, pencurian ikan 
dan sumber daya laut lain 4) Pemidahan tanda-tanda (patok) batas wilayah yang sangat sederhana oleh orang-orang yang tidak bertanggung jawab. 5) Meningkatnya kriminalitas, pencurian hasil bumi, ternak, kendaraan bermotor yang kemudian diselundupkan lewat jalan tikus baik ke luar maupun ke wilayah RI.

Kasus-kasus tersebut tidak terlepas dari sistem pengamanan perbatasan kita yang belum memadai. Bahkan ada kecurigaan masyarakat bahwa pihak keamanan sepertinya berkolusi dengan para pelaku karena juga memperoleh keuntungan dari pelanggaran-pelanggaran tersebut. Sebagai bagian dari masyarakat internasional tentunya batas-batas yang jelas secara yuridis perlu mendapatkan pengakuan baik secara regional maupun internasional. Tidak kalah pentingnya, pengakuan tersebut juga perlu dimengerti dan dipahami masyarakat maupun aparat penegak hukum, khususnya yang berada atau yang berinteraksi dengan masyarakat di wilayah perbatasan.

Persoalan secara fisik bagi pengguna peta wilayah perbatasan apabila menggunakan peta dasar Topografi yang overlap dengan border line (garis batas) di mana berbeda sistem proyeksi dan datum referensinya, walaupun bisa dilakukan penyesuaian perhitungan transformasinya, namun perlu pengujian posisi di lapangan. Permasalahan di laut, khususnya berkaitan dengan masalah kapal-kapal nelayan asing dan pencurian ikan ditinjau dari sisi hukum laut internasional banyak terletak dari perbedaan persepsi dalam penarikan garis batas laut antarnegara, misalnya antara RI-Malaysia, RI-Thailand, RI-Australia. Sedangkan permasalahan di darat, terutama banyak berkaitan dengan ketidakjelasan segmen-segmen (gap) yang ada. Perselisihan segmen tersebut dapat berupa belum adanya kesepakatan atau akibat ambigius penafsiran dan ketidksadaran warga di sekitar perbatasan.

Pengelolaan perbatasan tidak dapat dilakukan secara sektoral, melainkan perlu dilakukan secara profesional dan lintas sektoral. Melalui Keppres No 161 tahun 1999, di Indonesia penanganan masalah secara koordinatif khusus berkaitan dengan masalah batas laut ditangani oleh Dewan Maritim Indonesia (DMI). Penangan kasus oleh DMI dilakukan dengan pendekatan kasuistik, ad hoc, dan berkoordinasi dengan Departemen teknis yang berkepentingan. Pada kenyataannya, dalam kasus-kasus tertentu upaya yang menjadi kendala DMI adalah seringkali sulit mempertemukan skala prioritas dalam penanganan masalah diantara departemen yang saling terkait. Meskipun demikian, dalam pengelolaan perbatasan memang tidak perlu harus membentuk badan-badan baru, lembaga dan instansi yang saling terkait harus bisa berkoordinasi dengan profesional dalam mengorganisir, menganggarkan, mendiplomasikan, dan mendokumentasikan tindakan yang dilakukan. Dalam hal ini TNI dapat menjadi koordinator dari sistem kerjasama tersebut, mengingat penanganan masalah perbatasan sangat erat kaitannya dengan masalah pertahanan dan keamanan serta kedaulatan negara.

Selain aspek kelembagaan, pengelolaan perbatasan juga perlu memperhatikan aspek-aspek yang sifatnya teknis. Aspek teknis di sini dimaksudkan sebagai faktor yang harus diperhitungkan dalam menopang penyelenggaraan pengelolaan batas wilayah negara, khususnya dalam produk survei dan pemetaan wilayah perbatasan. Kasus-kasus pelanggaran batas wilayah negara yang pernah terjadi pada akhirnya akan menggunakan sarana pembuktian atas posisi di mana terjadi pelanggaran atau sengketa di wilayah tersebut. Pada aspek teknis 
penggunaan teknologi memang sangat membantu dalam menentukan segmentasi dan batas-batas. Saat sekarang ini teknologi seperti General Positioning System (GPS) telah banyak digunakan untuk memberikan nilai koordinat geografis.

Dalam kaitannya dengan Timor Leste, baru-baru ini penggunaan sarana Citra Satelit Ikonos dan Peta Topografi skala 1: 25.000 untuk penyesuaian spesifikasi teknis bersama. Rencana kerja kedua negara secara menyeluruh baik dilineasi maupun demarkasi direncanakan akan selesai pada tahun 2005. Sampai dengan bulan Agustus tahun 2005 berdasarkan laporan hasil Kerja Menteri Luar Negeri Indonesia dan Menlu Timor Leste, telah 96\% batas wilayah kedua negara yang berhasil dituntaskan. Masalah-masalah pada beberapa segmen yang masih tersisa diharapkan dapat selesai pada akhir tahun.

Satu-satunya masalah yang sangat mendesak berkaitan dengan aspek teknis adalah pengamanan di perbatasan. Kondisi ini juga yang menjadi keluhan sebagian besar warga, terutama berkaitan dengan meningkatnya kriminalitas di wilayah perbatasan. Namun kondisi ini sebenarnya tidak secara penuh harus disalahkan kepada warga Timor. Tidak menutup kemungkinan pula bahwa ada warga dari Indonesia sendiri yang memanfaatkan situasi untuk kepentingan pribadi. Secara teknis kedua negara memang telah bersepakat untuk segera melakukan pertemuan guna membahas masalah penangan keamanan di perbatasan, mengingat pengaturan sebelumnya juga sudah habis masa berlakunya.

Aspek yuridis dalam penanganan masalah perbatasan juga tidak kalah pentingnya. Aspek yuridis sangat krusial karena sebagai negara yang berdaulat dan legitimated di dunia internasional, batas wilayah negara harus memenuhi kriteria berupa kepastian hukum, yakni ada produk hukum yang mengatur dan menetapkannya. Apabila wilayah yang dibatasi itu memuat hak dan kewajiban negara atau masyarakat yang bersifat mendasar, seperti wilayah negara, wilayah dengan hak milik, maka batas yang dibuat itu harus diatur dalam bentuk undangundang atau setidaknya Peraturan Pemerintah.

Sebagian besar Keppres dan persetujuan batas landas kontinen dengan negara tetangga di negara Indonesia tidak diatur dengan undang-undang. Masalah lain lagi adalah mengenai ketidakkonsistenan antara kedua negara dalam menentukan desimal batas. Apabila disimak secara jelas, banyak perjanjian-perjanjian yang dibuat berbeda dalam nilai desimal koordinat geografis (ada koordinat yang lengkap hingga sekon dan ada tanpa sekon, melainkan hanya sampai menit). Tentunya ketidaksamaan desimal nilai koordinat geografis sebagai dasar penarikan garis-garis batas wilayah yang telah disepakati dengan negara tetangga masih perlu disatukan dalam sistem referensi geografis yang tunggal, mengingat teknologi dalam penentuan posisi sekarang jauh lebih teliti dibandingkan pengukuran di masa lalu.

\section{Kepentingan dan Motif-motif Penduduk Melintasi Batas}

Beberapa motivasi atau alasan penduduk melintasi perbatasan didasari pada kepentingan yang aneka ragam meliputi motif ekonomi (berdagang, belanja), motif sosial, budaya, dan motif politik. Sebagian penduduk baik warganegara Indonesia maupun warganegara Timor Leste ada yang masih terbawa kebiasaan lama dalam melakukan aktivitas ekonominya terutama dalam bentuk berdagang barang-barang kebutuhan sehari-hari seperti bahan makanan, sayuran, bahkan BBM. Bukan tidak 
mungkin mereka melakukan kegiatan ini memang disengaja karena adanya disparitas harga yang cukup tinggi antara berbelanja atau berjualan di wilayah Atambua, Nusata Tenggara Timur (Indonesia) dengan di wilayah Timor Leste.

Sedangkan secara social-budaya, bagaimanapun ini tidak bisa dihindarkan karena sebagian penduduk yang awalnya menjadi warga Indonesia kemudian berpindah kewarganegaraan, atau sebaliknay mereka yang tetap memilih menjadi warga negara Indonesia sementara saudara-saudara mereka berpindah menjadi warga Negara Timor Leste dan sebaliknya. Dalam konteks ini mereka dalam saatsaat tertentu untuk saling mengunjungi saudara-sadara mereka yang berada di ke dua negara. Motif seperti ini akan semakin tinggi intensitasnya terutama pada saat momentum hari hari besar keagamaan (Natal, Paskah, atau Idul Fitri, dan lain-lain) maupun hari-hari besar nasional dari kedua Negara.

Motif yang lain, bukan tidak mungkin karena adanya motif politik terutama pada saat di kedua wilayah negara yang berbeda tersebut terjadi momentum peristiwa politik seperti pilkada, pileg maupun pilpres, dengan motif utama adalah untuk memperluas dukungan suara. Satu lagi yang masih perlu dilakukan penelitian yang lebih mendalam adalah motif yang berhubungan dengan misi rahasia untuk mengorek informasi tertentu berkait dengan kebijakan-kebijakan tertentu. Sekali lagi motif ini masih bersifat dugaan yang masih diperlukan penelitian lanjutan yang lebih mendalam.

\section{Hambatan-Hambatan dalam Pelayanan dan Pengawasan Keimigrasian}

Adapun hambatan/kendala dalam pelayanan dan pengawasan keimigrasian yang penyusun amati dan ikut merasakan langsung selama melaksanakan praktek kerja lapangan pada Tempat Pemeriksaan Imigrasi Mota'ain di Pos Lintas Batas Darat adalah yakni terkait letak Pos Pelayanan, luas ruang pelayanan yang, listrik dan penerangan, petugas porter serta percaloan. Pos Lintas Batas Darat Mota'ain dikelilingi oleh pasar tradisonal dan jaraknya yang begitu dekat dengan garis perbatasan, hal ini sering menyulitkan petugas Pos Lintas Batas dalam memantau para pelintas batas baik dari wilayah Indonesia Maupun dari Negara Republik Democratic Timor Leste.

Ukuran pos pelayanan yang begitu sempit sering menghambat pelayanan baik keberangkatan maupun kedatangan sehingga petugas bergerak tidak leluasa dalam melayani pelintas, bila musim hujan keadaan di sekitar pos menjadi becek dan berlumpur sedangkan musim panas menyebabkan debu akibat keluar masuknya kendaraan ekspedisi.

Listrik dan penerangan yang terbatas bahkan sering padam menghambat petugas saat pengetikan data dan pekerjaan menjadi menumpuk bila terjadi konslet atau padam listrik sehingga pendataan yang harusnya didata pada hari itu akan dikerjakan pada hari berikutnya. Keterbatasan petugas porter membingungkan petugas akibat adanya kesamaan karakter antara pelintas warga negara Timor Leste dan porter yang bekerja mengisi Id Card dan mengangkat barang bawaan pelintas batas. Kondisi ini diperparah dengan maraknya percaloan yang di lokasi pos pelayanan perbatasan. 


\section{SIMPULAN}

\section{Kesimpulan}

Beberapa kesimpulan terkait pelayanan dan pengawasan terhadap pelintas batas oleh Kantor Imigrasi Kelas II Atambua di Tempat Pemeriksaan Imigrasi di Pos Lintas Batas Darat Mota'ain Perbatasan Indonesia - Timor Leste adalah:

1. Sebelum pelintas batas keluar wilayah Indonesia dan memasuki area Imigrasi maka instansi yang berwenang melakukan berbagai persiapan untuk melakukan pengawasan dan pelayanan akan kebutuhan pelintas sebelum berangkat ke Timor Leste. Setelah alat angkut tiba dan memasuki area Imigrasi maka masingmasing instansi melakukan pelayanan sesuai dengan tugasnya di Pos Lintas Batas Darat Mota'ain setelah menerima pemberitahuan dari penangung jawab alat angkut. Pelintas batas melaporkan diri kepada seluruh instansi yang ada untuk di data bahwa pelintas tersebut sedang melakukan perjalanan keluar atau masuk wilayah Indonesia. Setelah melaluli seluruh proses pelayanan dan pemeriksaan terhadap pelintas batas, maka keputusan terakhir untuk dapat masuk atau keluar wilayah Indonesia akan diberikan oleh Pejabat Imigrasi setelah pelintas mendapat tanda masuk atau keluar berupa cap.

2. Problematika yang dihadapi di area pos pemeriksaan lintas batas mencakup Pelanggaran prosedur keimigrasian, yaitu pelintas batas secara ilegal. Penyelundupan barang/orang secara illegal. Pencurian sumber daya alam pada wilayah-wilayah yang sulit atau jauh dari jangkauan pengawasan, misalnya pembalakan hutan secara ilegal, pencurian ikan dan sumber daya laut lain. Meningkatnya kriminalitas, pencurian hasil bumi, ternak, kendaraan bermotor yang kemudian diselundupkan lewat jalan tikus baik ke luar maupun ke wilayah RI.

\section{Saran}

Berdasarkan kesimpulan di atas maka penyusun dapat memberikan masukaan atau saran sebagai berikut :

1. Perlu adanya perhatian khusus Badan Nasional Pengelolah Perbatasan (BNPP) mengenai keadaan Pos Lintas Batas Darat Mota'ain dalam mengelola pelayanan dan pengawasan terhadap masyarakat pelintas batas. Fasilitas utama berupa sarana dan prasarana seperti gedung, kendaraan operasional serta fasilitas penunjang seperti, pos pelayanan, perbaikan jalan, penyediaan mesin $X$-Ray, penyediaan jaringan internet sehingga membantu kelancaran pelayanan dan pengawasan terhadap pelintas yang keluar atau masuk wilayah Indonesia.

2. Perlu ditingkatkan kerjasama yang lebih kuat antara institusi keimigrasian yang ada di Indonesia dengan institusi sejenis di bawah pemerintahan Timor Leste. Beberapa poin penting dalam kerjasama tersebut mencakup hak-hak dan kewajiban petugas pelayanan dan pemeriksaan, ketegasan sanksi yang disepakati kedua belah pihak dan sebagainya.

3. Untuk mengoptimalkan pelayanan, Kantor Imigrasi Kelas II Atambua agar menambahkan personil khususnya Intelijen Keimigrasian agar melakukan pengawasan pelintas di pasar tradisional Mota'ain. Petugas agar lebih teliti dalam melayani dan memantau pelintas batas serta penguasaan bahasa inggris yang lebih dalam agar mudah melayani pelintas asing. 
4. Peran aparat setempat untuk secara kontinyu mensosialasikan kepada warga masyarakat perbatasan. Pejabat pemerintahan dari bupati sampai dengan ketua RT setempat punya peran yang sangat sentral dalam memberikan pemahaman kepada setiap warga masyarakat agar tercipta layanan yang terbaik di pos lintas batas.

\section{DAFTAR PUSTAKA}

Anton M. Moeliono, 1990, Kamus Besar Bahasa Indonesia, Balai Pustaka, Indonesia, Jakarta.

Cholid Nurboko, Drs.,Abu Achmadi,2005, Metodologi Penelitian, Bumi Aksara, Jakarta.

Fauzan, 2011 Disampaikan pada acara Indonesia-Timor Leste Seminar and Conflict Resolution Training : Bulding Peace Beyond the Land Border, Kelompok Studi Defensia Laboratorium Pertahanan dan Keamanan asosiasi Mahasiswa Timor Leste UPN Veteran, Yogyakarta. 10 Juni 2011

Manullang, Drs., M., 1992 Dasar-Dasar Manajemen, Ghalia Indonesia, Jakarta M. Iman Santoso, "Perspektif Imigrasi dalam Pembangunan Ekonomi dan Ketahanan Nasional”, (UI Press, 2004), hlm. 1.

Panglaykim Dr., 1992 Manajemen Suatu Pengantar, Ghalia Indonesia, Jakarta

Strake, J. G, 1989, “Pengantar Hukum Internasional I”, Sinar Grafika: Jakarta.

Wuryandari (Ed) Ganewati, 2009, “Keamanan di Perbatasan Indonesia-

Timor Leste", Pustaka Pelajar LIPI: Yogyakarta.

Undang-undang RI Nomor 6 Tahun 2011 "tentang Keimigrasian”, .

Peraturan Presiden No. 12 Tahun 2010, "tentang Badan Nasional Pengelola Perbatasan".

Website Resmi Kantor Imigrasi Kelas II Atambua : http//atambua.imigrasi.go.id http://www.imigrasi.go.id/index.php/profil/tugas-fungsi.

(http://atambua.imigrasi.go.id/index.php/wilayah/pelayanan/UPT,

(http://atambua.imigrasi.go.id/index.php? me =detailberita $\& m k=$ Berita $\&$ kode $=1$ 9) 